\title{
Federal Remedies for Voteless Negroes
}

\author{
Ira Michael Heyman*
}

TN 1958 The United States Commission on Civil Rights, ${ }^{1}$ pursuant to

congressional mandate, embarked on an examination of civil-rights and minority-group problems in the United States. The enabling legislation designated three special areas of inquiry: voting, equal protection of the laws, and federal laws and policies relating to the equal protection of minorities. ${ }^{2}$ At the conclusion of its study five of the six members of the Commission concurred that the problem of civil rights in the United States "is one of securing the full rights of citizenship to those Americans who are being denied in any degree that vital recognition of human dignity, the equal protection of the laws." 3 The Commission found that one of the rights of citizenship denied to significant numbers of Southern Negroes is the right to vote. It also found that the discriminatory application of voting qualification standards by certain registration officials posed one of the more important obstacles to such voting. Stimulated by the report, Congress, after a bitter fight, adopted an administration proposal providing for limited federal intervention in behalf of disenfranchised Negroes to overcome the effects of that and other obstacles. ${ }^{4}$ This paper will discuss the new congressional act, other existing federal remedies available to enforce voting

* Acting Associate Prófessor of Law, School of Law, University of California, Berkeley. B.A., Dartmouth College, 1951 ; LL.B., Yale University, 1956.

1 The Commission on Civil Rights was created by Congress in 1957. It is an independent executive agency whose members were appointed by the President sulject to confirmation by the Senate. The statute creating the Commission, Civil Rights Act of 1957, $\$ \$ 101-06,71$ Stat. 634,42 U.S.C. $\$ \$ 1975-75$ e (1959), as amended, 42 U.S.C.A. \$1975c (Supp. 1959), has been described as a legislative compromise between the proponents and opponents of increased congressional action in the civil-rights field. Sec Storey, The Report of the Commission on Civil Rights, 46 A.B.A.J. 39 (1960); Report of the United States Commission on Crvit Riguts, at ix-xi (1959) [hereinafter, REPORT]; Comment, 43 CoRner. L.Q. 661 (1958); Comment, 56 Micr. L. Rev. 619 (1958); Book Note, 43 Notre Darie Law. 790 (1959). The Commission's life, originally 2 years, was extended to 4 years in 1959 by the Act of Sept. 28, 1959, tit. IV, 73 Stat. 724, amending 71 Stat. 635 (1957), 42 U.S.C.A. \$1975c(b) (Supp. 1959).

2 Civil Rights Act of 1957, § 104(a), 71 Stat. 635, 42 U.S.C. \$ 1975c(a) (1958).

3 REPORT 545.

4 Civil Rights Act of 1960, 74 Stat. 86 (P.L. 86-449, approved Maly 6, 1960). See S. REP. No. 1205, H.R. REP. No. 956, 86th Cong., 2d Sess. (1960).

The limited intended scope of this Article makes it impossible to recount the fascinating legislative history of this statute. Perbaps a student of the legislative process will see fit in the near future to prepare such an account. It could well rival in interest and instruction that excellent fictional presentation, Advise and Consent. 
rights, and proposals of the Commission on Civil Rights and others designed to the same ends but not enacted into law.

In the Commission's view the "right to vote is the cornerstone of the Republic, and the key to all other civil rights." Events tend to support this statement. The official treatment of Negroes where the franchise is unrestricted seems relatively better than where Negro voting is minimal. In New York City, for instance, where Negroes vote in roughly the same proportion as whites, the city council has passed anti-discrimination measures in the field of housing. ${ }^{6}$ The recently adopted policy of the New York State Board of Regents to assure integration in schools racially "segregated" by housing patterns is undoubtedly in part a response to the political power now wielded by a large Negro minority. ${ }^{7}$ The relatively better treatment of Negroes in housing and education in Atlanta, Georgia, has gone hand in hand with their increased voting. ${ }^{8}$ Seventeen States with growing Negro voting populations have passed anti-discrimination laws of varying coverage and have established admimistrative agencies to secure compliance. ${ }^{\ominus}$ Thirteen of these States and thirty-four cities or counties have anti-discrimination housing laws. ${ }^{10}$ Sixteen of these States have laws on fair employment practices which provide for enforcement by commission procedure, ${ }^{11}$ while twenty-four have laws banning discrimination in public accommodations. ${ }^{12}$

The correlation can, of course, be overemphasized. Better treatment of Negroes in many Northern communities is undoubtedly due in part to a cultural and historical heritage which is reflected in the racial attitudes of majority group menibers. Furthermore, the inimediate enfranchisement of all potential Negro voters does not automatically result in the disappearance of every kind of discrimination. But it can probably be taken as a working hypothesis that wholesale enfranchisement of qualified Negroes in the United States would be a powerful factor in solving the problem of second-class citizenship. The threat of organized bloc voting would give political leaders pause in advocating the continuance of evident discriminatory practices.

On the less pragmatic level, responsible Americans seem to agree that freedom from discrimination on racial, religious, or ethnic grounds in exercising voting rights is a basic value of a democratic society. ${ }^{13}$

6 REPORT 19.

6 Administrattve Code of Ctty of New York tit. X, ch. 41, \& 1 (Supp. 1959).

7 N.Y.Times, Jan. 29, 1960, p. 10, cols. 5, 6.

8 REPORT 66, 419-28.

9 Based on data in Aarertcan Jewish Congress, Report on Eighteen State AntiDiscriarnation Agencies and the Laws They Admonister (1959).

10 Ibid.

11 Ibid.

12 Ibid.

${ }^{13}$ See, e.g., REPORT 19 (statements by Senators Johnston, Saltonstall and Douglas, and Attorney General Brownell); Horsky, The Supreme Court, Congress, and the Right to Vote, 20 O\#̈о ST. L.J. 549 (1959). 
In the Civil Rights Act of $1957^{14}$ Congress indicated its concern that qualified persons are being barred from the polls due to discrimination. The act, inter alia, directed the Civil Rights Commission to

investigate allegations in writing under oath or affirmation that certain citizens of the United States are being deprived of their right to vote and have that vote counted by reason of their color, race, religion, or national origin; which writing, under oath or affirmation, shall set forth the facts upon which such belief or beliefs are based .... ${ }^{14 a}$

The Commission received complaints involving twenty-nine counties in eight States which resulted in a unanimous decision to conduct an investigation. The Commission held hearings in Alabama and, through its investigators, amassed data concerning voting practices in counties in other States. The information gathered paints a picture of heretofore suspected (and in many instances demonstrated) discriminatory practices against prospective Negro voters in many areas of the South. ${ }^{15}$ Some instances of relatively unimpeded voting were uncovered. In Atlanta, Georgia, for instance, a high percentage of Negroes are registered and do vote. But in numerous counties in the South, especially rural counties with a high percentage of Negro inhabitants, Negro voting is at a minimum and sometimes does not exist at all. ${ }^{16}$

I

\section{OBSTACLES TO NEGRO VOTING}

The Commission's published Report canvasses many methods used to to deny equal voting rights to Negroes. At this point the obvious should be noted: the low voting statistic among Negroes is not solely the product of

14 Sections $101-06,71$ Stat. 634,42 U.S.C. $\$ \$ 1975-75$ e (1958), as amended, 42 U.S.C.A. $\$ 1975$ c(b) (Supp. 1959); $\$ 131,71$ Stat. 637, amending REv. STaT. $\$ 2004$ (1875), 42 U.S.C. $\S 1971$ (1958).

14a Section 104(a)(1), 71 Stat. 635, 42 U.S.C. $\$ 1975$ c(a) (1) (1958).

15 See, e.g., Key, Soutuern Politics in State and Nation (1949); McGovney, The Aarerican Suffrage Mediey (1949); U.S. President's Commassion on Civil Rigits, To Secure These Rigets (1947); Price, The Negro and the Baliot in the South (Southern Regional Council 1959); Fenton \& Vines, Negro Registration in Louisiana, 51 AM. PoL. Sc1. Rev. 704 (1957); Maslow \& Robison, Civil Rights Legislation and the Fight for Equality, 1862-1952, 20 U. CHI. L. REv. 363 (1953) ; Symposium, The Negro Voter in the South, 26 J. Negro Ed. 213 (1957); Note, 47 Colum. L. Rev. 76 (1947).

${ }^{16}$ The Commission concluded that as of $1956,60 \%$ of the Southern white population of voting age was registered while only $25 \%$ of the comparable Negro group was registered. County figures.in Southern States, however, were very uneven. In some counties well over $50 \%$ of voting-age Negroes were registered. In numerous others, especially those with a majority nonwhite population, Negro registration was nearly nonexistent. Some stark examples of the latter situation are presented in tables, taken from similar tables in the Report at 587-91, set out in the appendix to this Article.

It should also be noted that since 1940 increased numbers of Negroes have voted at many; Southern clections. Maslow \& Robison, Civil Rights Legislation and the Right for Eqtulity, 1862-1952, 20 U. Cm. L. Rev. 363, 379-80 (1953); Moon, The Negro Vole in the South, 175 Natron 245 (1952); Strong, The Rise of Negro Voling in Texcls, 42 AM. PoL. Scr. Rev. 510 (1948). 
discrimination. Lack of education and apathy also play a role. Neither of these factors, however, can completely account for the absence of any Negro participation in political activities in some Southern locales and the insignificant participation in many. ${ }^{17}$ This lack of Negro voting results in large part from obstacles constructed by whites. The obstacles found by the Commission can be classified into five groups: (1) patently discriminatory state enactments; (2) state enactments that are not discriminatory on their face but result in discrimination; (3) patently discriminatory actions by state officials; (4) covert discriminatory actions by state officials; and (5) actions of private individuals.

The first category, patently discriminatory state enactments, includes the white primary laws and literacy tests with grandfather clauses. These devices no longer raise significant problems because they are clearly unconstitutional and easily discovered. ${ }^{18}$ Both seem to have fallen into disuse.

The second category, state enactments which are not discriminatory on their face but result in discrimination, includes poll taxes and gerrymandering. The proponents of bills introduced in Congress to prohibit poll taxes believe that property qualifications are outmoded and that poll taxes are in reality a device to discourage Negro participation in elections. ${ }^{19}$ However, in view of the nominal amounts assessed and the limited cumulative provisions found in the five poll tax statutes still in force it is probable that such taxes no longer present a significant bar to Negro voting. ${ }^{20}$ Gerrymandering, too, seems of limited significance at this time. So far there is only one reported instance where a State has redistricted local boundaries to disenfranchise Negro voters who previously had a voice in city government. ${ }^{21}$ Probably the patterns of population distribution in the South preclude this as an effective device. Furthermore, redistricting cannot significantly affect the rights of Negroes to cast ballots for federal officials because regardless of town and city boundaries a State must include all of its population in its congressional districts.

The third category of obstacles to Negro participation in political activities, patently discrminatory actions by state officials, includes the refusal

17 See note 16 supra.

18 The restriction of voting to whites in primary elections is invalid even where apparently "private" organizations administer the vote. Terry v. Adams, 345 U.S. 461 (1953); Smith v. Allwright, 321 U.S. 649 (1944); Nixon v. Condon, 286 U.S. 73 (1932); Nixon v. Herndon, 273 U.S. 536 (1927); see Spicer, The Supreme Court and Racial Discrimination, 11 VAND. L. REv. 821 (1958). Similarly, the application of hiteracy tests with grandfather clauses designed to bar Negroes but permit voting by otherwise unqualified whites is clearly unconstitutional. Lane v. Wilson, 307 U.S. 268 (1939); Guinn v. United States, 238 U.S. 347 (1915).

19 See MCGovNeY, op. cit. supra note 15; Maslow \& Robison, supra note 16, at 376; Spicer, supra note 18 , at 828 .

20 REPORT 116-18.

21 The Alabama Legislature by setting new boundaries for the City of Tuskegee excluded all but 10 of the 420 Negroes who previously had voted in city elections. REPORT 77. 
of state election officials to register Negroes, the failure of such officials to provide ample registration facilities for Negro applicants, the separation of Negro and white registration facilities, and the purposeful delay in registering Negro applicants. All these devices are presently in use in various Southern counties. ${ }^{22}$

The fourth category, covert discriminatory actions by state officials, includes devices similar to those just mentioned. They rate a separate classification because they are more difficult to discover and combat. Examples include the discriminatory application by election officials of valid criteria of voting qualification, such as literacy tests, and the resignation of election officials faced with heavy Negro registration. ${ }^{23}$

The last classification, actions of private individuals, comprehends mainly private acts of economic and physical intimidation and coercion directed at Negroes who seek to register or vote. The Commission alludes to a number of instances where such pressures were brought to bear. ${ }^{24}$ Other sources indicate that pressures of this nature (either blatant or subtle) are widespread. ${ }^{25}$

The devices that fall within the last three categories are particularly difficult to remedy by conventional judicial methods. The failure to provide adequate registration facilities for Negroes can be excused on administrative grounds, and it is difficult to prove an improper intent. Discriminatory application of qualification criteria is hard to show, and when criteria are broad and general it is difficult to demonstrate an abuse of discretion by registration officials. ${ }^{28}$ Private coercive action, even when patent, is difficult to show, and often such tactics are more implicit than explicit. But if Negroes are to cast ballots in areas where political power rests in the hands of persons set against a Negro vote, effective federal means must be provided to combat these devices.

This Article assumes that the primary goal of federal action in the voting field should be to aid significant numbers of qualified Negroes to avoid obstacles to registration and voting raised by conduct falling within the last three mentioned categories. The Article, however, discusses mainly the

22 REPORI 90-95.

23 For a listing of tactics frequently used by registration officials to discourage Ntgro voting, see, Key, op. cit. supra note 15; RePort 55; Southern Regional Councir, TEe CondiTION of OUR RIGETS (1948). On the resignation of registration officials, see Sellers v. Wilson, 123 F. Supp. 917 (M.D. Ala. 1954); Equality Before the Law: A Symposium on Civil Rights, 54 Nw. U.L. REv. 330, 369-70 (1959).

24 REPORT 56-58, 60, 64, 78-79, 94, 96-97.

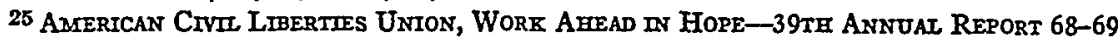
(1960); Carter, The South Strikes BaCk 107-42 (1959); Price, op. cit. supra note 15, at 6, 15-16, 21, 26, 58, 59-61; N.Y.Times, Mar. 19, 1960, p. 1, col. 6; id., Mar. 20, 1960, 84 (Magazine), p. 6, cols. $1-4$.

${ }^{28}$ See, e.g., Williams v. McCulley, 128 F. Supp. 897 (W.D. Ira. 1955). 
problems faced by Negroes who are the victims of discrimination in the application of valid voting standards by registration officials (covert actions which fall in the fourth category). The problem of covert action by state officials is emphasized because it is believed that any remedy that successfully combats this type of discrimination will also combat patently discriminatory actions by state officials and will, in large measure, minimize the effectiveness of private intimidation and coercion by providing a simple and rapid means for the registration and voting of so large a number of qualified Negroes as to make the use of such tactics impractical.

A number of studies have established the existence of discriminatory application of valid voting criteria. ${ }^{27}$ Perhaps the most evident discrimination occurs in the application of literacy and character tests. For instance, Alabama requires that a voter be able to read and copy any provision of the United States Constitution..$^{28}$ White applicants have been asked to deal with a relatively simple provision of the Constitution while Negro applicants are required to read and copy two, three, or more articles. Alabama, moreover, makes the registrar's judgment final concerning whether the applicant satisfies the literacy requirement and also whether he is of "good character" and "embrace[s] the duties and obligations of citizenship under the constitution of the United States and under the constitution of the state of Alabama." 20 Under these broad standards it is easy to see how Negroes might be unfairly disqualified. This simple example can be nultiplied. The Alabama investigation uncovered the fact that in Macon County, Negroes who made inconsequential errors on their registration forms were denied

27 RePORT 90-95; Equality Before the Law, A Symposium on Civil Rights, 54 Nw. U.L. REv. 330, 368-71 (1959); Note, 31 Notre DAME LAW. 251 (1956); see authorities cited note 15 supro.

28 AIA. CoNST. art. 8, $\S 181$ (Amend. No. 91, 1951). Compare Amend. No. 55 (1946) to this section, declared unconstitutional in Davis v. Schnell, 81 F. Supp. 872 (S.D. Ala.), aff'd per curiam, 336 U.S. 933 (1949).

29 ALA. Const. art. 8, $\$ 181$ (Amend. No. 91, 1951). Compare Miss. Const. art. 12, § 244, which provides "Every elector shall ... be able to read and write any section of the Constitution of this State and give a reasonable interpretation thereof to the county registrar. He shall demonstrate to the county registrar a reasonable understanding of the duties and obhgations of citizenship under a constitutional form of government. The person applying to register shall make a sworn, written application for registration on a form to be prescribed by the state board of election commissioners, exhibiting therein the essential facts and qualifications necessary to show that he is entitled to register and vote, said application to be entirely written, dated and signed by the applicant without assistance or suggestion from any person or memorandum whatever; provided, however, that if the applicant is unable to write his application by reason of physical disability, the same, upon his oath of such disability, shall be written at his unassisted dictation by the county registrar. Any new or additional qualifications herein imposed shall not be required of any person who was a duly registered and qualified elector of this state prior to January 1, 1954." The Mississippi provision was attacked unsuccessfully in Darby v. Daniel, 168 F. Supp. 170 (S.D. Miss. 1958). 
registration while whites who made similar errors were permitted to register..$^{30}$

Voting by qualified Negroes, in large measure, depends on the good faith application of nondiscriminatory criteria by local officials. The Commission's investigations show that nondiscriminatory enforcement is lacking in many Southern counties and this lack accounts in large measure for the low percentage of registered Negro voters.

\section{II}

\section{REMIEDIES}

Prior to the adoption of the recent act, a number of existing federal remedies could be used to bring the power of the federal government to bear on state officials who unfairly applied qualification standards to prospective Negro voters. The recent act provides an expanded remedy. Its adoption resulted in the rejection of plans put forth by the Commission on Civil Rights and by others. Before launching into an examination of the remedies, however, it is valuable to take a brief look at the constitutional bases for congressional action in voting matters.

\section{A. Constitutional Bases for Congressional Action}

Article I, section 2, and the seventeenth amendment of the federal constitution provide that the people of each State who are qualified to be electors of the most numerous branch of the state legislature shall elect Senators and Representatives to the Congress of the United States. The Supreme Court has held that even though the States provide the standards of eligibility, the right of the people to vote for these offices stems from the federal constitution. ${ }^{31}$ Moreover, Congress, under article I, section 4 , has supreme authority to regulate the time, place and manner of holding elections for these offices. Court decisions have established that under these constitutional provisions, and under power inferred from the nature of our federal form of government, ${ }^{32}$ Congress has the power:

to provide a complete code for congressional elections, not only as to times and places, but in relation to notices, registration, supervision of voting,

30 REPORT 91.

31 United States v. Saylor, 322 U.S. 385 (1944) (Senator); United States v. Classic, 313 U.S. 299, 314-15 (1941) (Representative); United States v. Mosley, 238 U.S. 383 (1915) (Representative) ; Swafford v. Templeton, 185 U.S. 487, 491 (1902) (Representative); Wiley v. Sinkler, 179 U.S. 58, 62-64 (1900) (Representative); Ex parte Yarborough, 110 U.S. 651, 663-64 (1884) (Representative); see United States v. Aczel, 219 Fed. 917, 928-32 (D.C. Ind.1915), af'd, 232 Fed. 652 (7th Cir. 1916) (Senator).

32 Burroughs v. United States, 290 U.S. 534, 545 (1934); Ex parte Yarborough, sufpra note 31 . 
protection of voters, prevention of fraud and corrupt practices, counting of votes, duties of inspectors and canvassers, and making and publication of election returns; in short, to enact the numerous requirements as to procedure and safeguards which experience shows are necessary in order to enforce the fundamental right involved..$^{33}$

This power authorizes Congress to proscribe both state, ${ }^{34}$ and private ${ }^{35}$ acts of interference, in any portion of the political process ${ }^{38}$ leading to the election of Senators and Representatives. It also extends to the election of Presidential and Vice-Presidential electors. ${ }^{37}$ The detailed provisions enacted by Congress relating to elections and political activities ${ }^{38}$ attest to its understanding that such power exists.

The fifteenth amendment specifically prohibits both the United States and the States from denying a citizen the right to vote because of race, color, or previous condition of servitude. And it empowers Congress to enforce this command by "appropriate legislation." The fourteenth amendment, in part, prohibits the States from abridging the privileges and immunities of citizens of the Umited States and of denying any person the equal protection of the laws. The privileges and immunities there mentioned include the right to vote for national officers, ${ }^{39}$ and the equal protection clause undoubtedly prohibits state action that discriminates against prospective voters on the basis of color, religion, or ethnic origin. ${ }^{40}$ The fourteenth amendment, too, empowers Congress to enforce its provisions by "appropriate legislation." Neither amendment, of course, prohibits what is found to be private interference with voting rights.

The scope of the term "appropriate" for purposes of the amendments is broad. As a general matter, Congress has nearly unfettered scope to choose any means not specifically prohibited by the Constitution to exer-

33 Smiley v. IHolm, 285 U.S. 355, 366 (1932). See United States v. Gale, 109 U.S. 65 (1883);

Ex parte Clarke, 100 U.S. 399 (1879); Ex parte Siebold, 100 U.S. 371 (1879).

34 Ex parte Clarke, supra note 33; Ex parte Siebold, supra note 33.

35 Ex parte Yarborougb, 110 U.S. 651 (1884). The following cases involved the prosecution of imdividuals not identified as election officials or state officers. Fields v. United States, 228 F.2d 544 (4th Cir. 1955), cert. denied, 350 U.S. 982 (1956); Crolich v. United States, 196 F.2d 879 (5th Cir.), cert. denied, 344 U.S. 830 (1952) ; Prichard v. United States, 181 F.2d 326 (6th Cir.), aff'd mem., 339 U.S. 974 (1950) ; United States v. Chandler, 157 F. Supp. 753 (S.D.W. Va. 1957).

36 E.g., United States v. Classic, 313 U.S. 299 (1941) (primary election).

37 Burroughs v. United States, 290 U.S. 534 (1934).

3818 U.S.C. $\$ \S 591-612$ (1958).

39 Twining v. New Jersey, 211 U.S. 78, 97 (1908) (dictum).

${ }^{40}$ The author has found no case where a State attempted to deny voting rights to a group of citizens because of their religion or ethnic origin. It seems justified to presume, however, that such discrinination, in the absence of extraordinary circumstances, would be barred by the equal protection clause of the 14th amendinent. Cf. Nixon v. Condon, 286 U.S. 73 (1932); Nixon v. Herndon, 273 U.S. 536 (1927). 
cise its enumerated and implied powers. ${ }^{41}$ Similarly, Congress has been found to have like scope in choosing the means to effectuate the protections of the fourteenth amendment. ${ }^{42}$ Although there are no cases directly in point, it seems reasonable to assume that Congress has similar power to enforce the commands of the fifteenth amendment. ${ }^{43}$ In the few post-Reconstruction cases where provisions of the Civil Rights Act of 1870 were held unconstitutional, the Court found the "ends," i.e., the purposes, of the statutes unconstitutional-not the "means" designed to effectuate those "ends." tion and bear a legitimate relationship with the ends in view, the means are "appropriate."

\section{B. Pre-existing Federal Remedies}

The federal remedies existing prior to the recent act which may be invoked by Negroes to combat the discriminatory application of voting criteria by state election officials are limited in their potential effectiveness. They fall into three classes: (1) criminal prosecutions, (2) civil suits for damages or equitable relief brought by the complaining Negroes, and (3) suits for equitable relief brought by the United States in behalf of Negroes subject to such discrimination.

\section{Criminal Actions Under 18 U.S.C. Sections 241 and 242}

The two relevant criminal statutes are 18 U.S.C. sections 241 and 242. On first glance they appear to offer adequate means for prosecuting and convicting state election officials who refuse to register qualified Negroes for state and federal elections. On closer analysis, however, one finds that the protections offered Negroes by these statutes are relatively ineffective.

41 E.g., United States v. Darby, 312 U.S. 100 (1941) ; Legal Tender Cases, 110 U.S. 421 (1884) ; McCulloch v. Maryland, 17 U.S. (4 Wheat.) 316 (1819).

42 Ex parte Virginia, 100 U.S. 339, 345-46 (1879).

43 Two courts have recently held that the Civil Rights Act of 1957 is "appropriate legislation" to enforce the 15th amendment. In re Wallace, 170 F. Supp. 63 (M.D. Ala. 1959); United States v. McElveen, 177 F. Supp. 355 (E.D. La. 1959), aff'd sub nom., United States v. Thomas, 80 Sup. Ct. 612 (1960). In those cases in which congressional enactments were invalidated as inappropriate to enforce the 15th amendment, the Court found the ohject or purpose of the statutes hroader than the protections of the amendment. See note 44 infra.

44 United States v. Reese, 92 U.S. 214 (1876); James v. Bowman, 190 U.S. 127 (1903); Minor v. Fapersett, 88 U.S. (21 Wall.) 162 (1875) ; see United States v. Raines, 172 F. Supp. 552 (M.D. Ga. 1959) (holding $\$ 131$ of the Civil Rights Act of 1957 invalid on similar grounds), rev'd, 80 Sup. Ct. 519 (1960); cf. Larche v. Hannah, 176 F. Supp. 791, 177 F. Supp. 816 (W.D. La. 1959), argument ordered on petition for cert. and merits, 80 Sup. Ct. 263 (1959) (holding that the rules of procedure of the Civil Rights Commision violate $\$ 7$ (c) of the Administrative Procedure Act, 60 Stat. 241 (1946), 5 U.S.C. $\$ 1006$ (c) (1958)). 
Section $242^{45}$ is most relevant because it is directed against persons acting under color of state law. It proscribes the wilful subjection of inhabitants of States under color of state law to the deprivation of any rights, privileges, or immunities secured by the Constitution or laws of the United States. A violation of the statute is a misdemeanor. United States $v$. Classic ${ }^{48}$ makes it clear that the right of qualified voters to cast their ballots for federal officials is secured by the Constitution and that a wilful denial of this right by state election officials is punishable under the section. In addition, Lane v. Wilson ${ }^{47}$ and other cases, ${ }^{48}$ hold that "rights, privileges, or immunities secured by the Constitution" include the rights of qualified persons to vote in any election free from racial discrimination imposed under color of state law. Thus it would appear that section 242 proscribes discriminatory application of voting criteria by state election officials in both state and federal elections. ${ }^{49}$ And to this extent, the statute is clearly constitutional.

Section 241 is directed at the actions of individuals (not state officials) and, in relevant part, prohibits conspiracies "to injure, oppress, threaten, or intimidate any citizen in the free exercise or enjoyment of any right or privilege secured to him by the Constitution or laws of the United States."150 A violation of the statute is a felony. Under the reasoning of the opinion for the Court in United States $v$. Williams, ${ }^{51}$ this section protects only those rights of a citizen of the United States which arise from his relationship with the federal government and does not protect those rights which are only guaranteed by the Constitution from interference by the States. It would thus appear that the section is applicable only to state election of-

4518 U.S.C. $\$ 242$ (1958): "Whoever, under color of any law, statute, ordinance, regulation, or custom, willfully subjects any inhabitant of any State, Territory, or District to the deprivation of any rights, privileges, or immunities secured or protected by the Constitution or laws of the United States, or to different punishments, pains, or penalties, on account of such inhabitant being an alien, or by reason or bis color, or race, than are prescribed for the punishment of citizens, shall be fined not more than $\$ 1,000$ or imprisoned not more than one year, or both."

46313 U.S. 299 (1941).

47307 U.S. 268 (1939).

48 Terry v. Adams, 345 U.S. 461 (1953); Guinn v. United States, 238 U.S. 347 (1915); United States v. Reese, 92 U.S. 214 (1876).

49 See Byrd v. Brice, 104 F. Supp. 442 (W.D. La. 1952), aff'd, 201 F.2d 664 (5th Cir. 1953) ; cf. Davis v. Schnell, 81 F. Supp. 872 (S.D. Ala.), aff'd per curiam, 336 U.S. 933 (1949); United States v. Ellis, 43 F. Supp. 321 (W.D.S.C. 1942)

5018 U.S.C. $\$ 241$ (1958): "If two or more persons conspire to injure, oppress, threaten, or intimillate any citizen in the free exercise or enjoyment of any right or privilege secured to him by the Constitution or laws of the United States, or because of his having so exercised the same; or if two or more persons go in disguise on the highway, or on the premises of another, with intent to prevent or himder his free exercise or enjoyment of any right or privilege so secured-they shall be fined not more than $\$ 5,000$ or imprisoned not more than ten years, or both."

51341 U.S. 70 (1951). As to the scope of $\$ 241$ the Court was evenly divided, Justice Black concurring on separate grounds. 
ficials who obstruct the registration of qualified Negroes to vote in federal elections. This result follows because the right to vote in a federal election arises from a citizen's relationship with the federal government while the right to be free from racial discrimination in any election is a right secured against state interference by the fifteenth amendment. ${ }^{52}$ The Williams decision also indicates that it is immaterial that the defendant in a section 241 suit is a state official and the fact that he is does not enlarge the rights of the complainant protected by the section. ${ }^{53}$

Although these statutes create a constitutional basis for prosecuting state election officials, there are a number of practical difficulties which impede obtaining convictions.

First, both sections require a jury verdict of guilty. This has proved difficult to obtain in Southern communities in cases involving other than voting rights. ${ }^{54}$ There is no apparent reason to expect different results in voting cases.

Second, it is difficult to obtain the necessary evidence to present to a jury. Negroes must be found as witnesses who are willing to risk censure and retaliation by the white community. Presumably not many will come forward. An extensive record must be built. This requires thoughtful action by Negro complainants to obtain witnessed instances in which state officials acted improperly. And somehow evidence must be adduced to show that the registration officials exercised their broad discretion in bad faith in judging the literacy and character qualifications of Negro applicants. Such bad faith is difficult to prove. ${ }^{55}$

Third, section 241 requires proof of a conspiracy. Prosecution under the statute is impossible where a single registrar is responsible for the discrimination.

Fourth, in a section 242 prosecution the United States must prove that the defendant acted wilfully-that he intended to deprive the complaining witnesses of federal constitutional rights. ${ }^{58}$ As has been pointed out, this is a difficult burden to satisfy and permits the defense attorney to make the persuasive argument to the jury that only a constitutional lawyer would know enough to be able to harbor the requisite intent. ${ }^{.7}$

For these reasons and others, ${ }^{68}$ the federal criminal remedies are in-

52 See text at notes 31-44 supra. See also 3 RACE REI. L. REP. 133, 145-46 (1958).

53341 U.S. 70, 78 (1951).

54 See Putzel, Federal Civil Rights Enforcement: A Current Appraisal, 99 U. PA. L. Rev. 439, 449 (1951); Note, 47 CoruM. L. Rev. 76, 96 (1947).

65 See Putzel, supra note 54, at 451.

68 Screws v. United States, 325 U.S. 91 (1945).

67 Clark, A Federal Prosecutor Looks at the Civil Rights Statutes, 47 CoLurr. L. Rev. 175, 182-83 (1947); Putzel, supra note 54, at 450.

$68 \mathrm{~A}$ violation of $\$ 242$ is only a misdemeanor; hence its deterrence value is probably minimal. Perhaps, however, it is not of minor significance in the case of election officials who often are respected members of the community. 
adequate means to assure significant registration of qualified Southern Negro voters.

\section{Civil Actions Under "Section 1983" of the Civil Rights Acts}

Negroes may enforce their voting rights by suing state election officials in federal courts pursuant to "section 1983" of the Civil Rights Acts. This section provides for money judgments and equitable relief. ${ }^{60}$

Section 1983 is the civil counterpart of 18 U.S.C. section 242. It provides that persons who under color of state law subject citizens of the United States or persons within its jurisdiction to the deprivation of any rights, privileges, or immunities secured by the Constitution shall be liable to the party injured in an action at law or a suit in equity. ${ }^{61}$. Involved here, as in the case of section 242, are the rights of all qualified persons (1) to vote in federal elections and (2) not to be the subject of State-imposed racial discrimination in any election. ${ }^{62}$ Clearly the statute authorizes suits against registration officials for discrimination based on race, ${ }^{83}$ and to this extent is constitutional. ${ }^{84}$

The practical difficulties of using this section to obtain a money judgment are not unlike those encountered in using its criminal counterpart. Perhaps the only differences are that the plaintiff need not show "wilfulness" and his proof does not have to satisfy the jury beyond a reasonable doubt.

Although a civil suit for equitable relief under section 1983 avoids the barrier presented by juries sympathetic with the defendant, and to this extent offers a more realistic remedy for Negroes who are the victims of discrimination by registration officials, other impediments remain. Negro complainants seeking this renedy have to identify themselves to the white community and thereby run the risk of economic and physicial intimida-

69 Rev. Stat. $\$ 1979$ (1875), 42 U.S.C. $\$ 1983$ (1958) (derived from the Civil Rights Act of $1871, \mathrm{ch} .22, \S 1,17$ Stat. 13) [hereinafter referred to as section 1983].

co See generally Note, 66 HARv. L. Rev. 1285 (1953) (written when $\$ 1983$ was codified as 8 U.S.C. § 43). "Section 1985(3)" of the Civil Rights Acts, REv. STAr. $\$ 1980$ Third (1875), 42 U.S.C. § 1985 (3) (1958) (derived from the Civil Rights Act of 1871, ch. 22, § 2, 17 Stat. 13), also might be relevant. Unhike $\$ 1983$, it is directed at individuals, not state officers. It is no broader in coverage than $\S 1983$, however, and consequently it need not be evaluated for purposes of civil suits against state officers.

61 Section 1983 reads: "Every person who, under color of any statute, ordinance, regulation, custoin, or usage, of any State or Territory, subjects, or causes to be subjected any citizen of the United States or other person within the jurisdiction thereof to the deprivation of any rights, privileges, or immunities secured by the Constitution and laws, shall be liable to the party injured in an action at law, suit in equity, or other proper proceeding for redress."

62 See text at notes $45-49$ supra.

${ }^{83}$ Lane v. Wilson, 307 U.S. 268 (1939) ; Myers v. Anderson, 238 U.S. 368 (1915); Rice v. Elmore, 165 F.2d 387 (4th Cir. 1947), cert. denied, 333 U.S. 875 (1948).

B4 Ibid. 
tion. Proving a case is difficult, especially without the aid of the United States. Practically speaking, suits of this nature require the intervention of the National Association for the Advancement of Colored People, or a like organization, because it is doubtful that single individuals can find the resources necessary to support such a litigation. Furthermore, it seems unrealistic to expect that even individual Negroes with the necessary resources will institute costly and burdensome litigations merely to exercise voting rights. Perhaps class suits could alleviate these difficulties, but so far the lower federal courts have been hesitant in permitting class suits to enjoin discriminatory treatment by registration officials. ${ }^{65}$

\section{Suits by the United States Under "Section 1971" of the Civil Rights Acts}

The Civil Rights Act of 1957, enacting "section 1971" of the Civil Rights Acts, ${ }^{68}$ permits the Attorney General to institute a suit for equitable relief in behalf of Negroes who are the victims of discrimination in voting. ${ }^{67}$ Subsection (a) of section 1971 is a policy statement originally' a part of the Civil Rights Enforcement Act of $1870^{\circ 8}$ and provides that all qualified citizens shall be allowed to vote in all elections without distinction based on race or color. Subsection (c) provides that the Attorney General may institute a proceeding for preventive relief whenever any person has

65 See Price, The Negro and the Barcot in the South 43-44 (Southern Regional Council 1959). Compare Reddix v. Lucky, 252 F.2d 930 (5th Cir. 1958), with Sharp v. Lucky, 252 F.2d 910 (5th Cir. 1958).

${ }^{66}$ Section 131, 71 Stat. 637, 42 U.S.C. \& 1971 (1958), amending Rev. STAT. 82004 (1875) [hereinafter referred to as section 1971]. The section reads in part: "(a) All citizens of the United States who are otherwise qualified by law to vote at any clection by the people in any State, Territory, district, county, city, parish, township, school district, municipality, or other territorial subdivision, shall be entitled and allowed to vote at all sucl elections, without distinction of race, color, or previous condition of servitude; any constitution, law, custom, usage, or regulation of any State or Territory, or by or under its authority, to the contrary notwithstanding. (b) No person, whether acting under color of law or otherwise, shall intimidate, threaten, coerce, or attempt to intimidate, threaten, or coerce any other person for the purpose of interfering with the right of such other person to vote or to vote as he may choose, or of causing such other person to vote for, or not to vote for, any candidate for the office of President, Vice President, presidential elector, Member of the Senate, or Member of the House of Representatives, Delegates or Commissioners from the Territories or possessions, at any general, special, or primary election held solely or in part for the purpost of selecting or electing any such candidate. (c) Whenever any person has engaged or there are reasonable grounds to believe that any person is about to engage in any act or practice which would deprive any other person of any right or privilege secured by subsection (a) or (b) of this section, the Attorney General may institute for the United States, or in the name of the United States, a civil action or other proper proceeding for preventive relief, including an application for a permanent or temporary injunction, restraining order, or other order. In any proceeding hereunder the United States shall be liable for costs the same as a private person."

67 See generally Comment, 43 Cornelr L.Q. 661 (1958); Note, 11 HaRv. L. Rev. 573 (1958); Comment, 56 Mich. L. Rev. 619- (1958).

${ }^{68}$ Ch. 114, \& 1, 16 Stat. 140 (now Rev. Srat. \& 2004 (1875), as amended, 42 U.S.C. \$ 1971 (a) (1958)). 
engaged, or is about to engage in an act or practice which would be contrary to any person's right under subsection (a).

The statute has been attacked on constitutional grounds, and the attacks resulted in two conflicting federal district court decisions. ${ }^{69}$ In United States $v$. Raines ${ }^{70}$ the lower court held section 1971 unconstitutional because, in its view, the statute proscribed actions of individuals, as well as state officials, that impeded Negro voting in state and local elections. The argument ran that Congress had the power to regulate all aspects of federal elections and to prohibit state action that denied individuals voting rights on discriminatory grounds, but that Congress was without power to punish private individuals for'interfering with the rights of prospective Negro voters in state and local elections. Section 1971 (as interpreted by the court) covered all of these interferences and was, therefore, unconstitutional in significant part. The whole statute had to be disregarded because it was uncertain whether Congress would desire only a portion of it enforced. Thus, even though the suit in Raines was brought against state election officials and not private individuals, the indictment was quashed because the statutory basis for the suit was, in the court's view, wholly invalid.

In United States $v . M c E l v e e n,{ }^{71}$ on the other hand, the district court upheld the constitutionality of section 1971 as applied to the actions of state officials and others taken under color of state law.

The Supreme Court resolved the conflict by affirming $M c E l v e e n^{72}$ and reversing Raines. ${ }^{73}$ Central to its decision was the often-repeated rule of practice that bars the anticipation of constitutional questions not necessary under the facts presented by the case. ${ }^{74}$ The Clourt thereby held section 1971 constitutional as applied in Raines to discriminatory treatment of Negroes by state registration officials. ${ }^{75}$ And by affirming the $M c E l v e e n$ decision per curiam, the Court held section 1971 constitutionally applicable where members of white citizens councils in Louisiana conspired with state election officials to purge already registered Negroes from the voting lists by applying presumably valid disqualification standards to them but not to whites. ${ }^{78}$

69 United States v. McElveen, 177 F. Supp. 355 (1959), 180 F. Supp. 10 (E.D. La. 1960) (constitutional) ; United States v. Raines, 172 F. Supp. 552 (M.D. Ga. 1959) (unconstitutional).

70172 F. Supp. 552 (M.D. Ga. 1959), rev'd, 80 Sup. Ct. 519 (1960).

71177 F. Supp. 355 (E.D. La. 1959), 180 F. Supp. 10 (E.D.La. 1960).

72 Sub nom. United States v. Thomas, 80 Sup. Ct. 612 (1960).

7380 Sup. Ct. 519 (1960).

74 Id. at 522 .

75 In Raines the United States alleged that election officials engaged in acts intended to deny qualified Negroes the right to vote including the delayed handling of registration applications of Negroes, the arbitrary refusal to register Negroes, and the application of more stringent standards to Negroes than to white applicants. $172 \mathrm{~F}$. Supp. at 555.

${ }^{76}$ In McElveen, the United States proved that the citizens council by challenging already registered voters succeeded in disenfranchising $85 \%$ of the Negro voters of Washington Parish 
In view of the Court's holdings, the question is whether the section provides a practical means for assuring Negroes freedom from discriminatory treatment by registration officials.

Some of the weaknesses inherent in the remedies under sections 241, 242 , and 1983 are cured by the procedures provided in section 1971. As in the case of criminal prosecutions under section 241 and 242, the individual Negro does not have to move alone-he has the coercive and financial power of the United States behind him. And as in the case of equitable actions brought under section 1983, a successful suit does not depend on a local jury which might be biased. Election officials who discriminate against Negroes must appear before a federal judge who presumably is less apt to act on the basis of prejudice.

On the other hand, the prosecution of individual suits is a cumbersome and slow means for protecting the voting rights of significant numbers of qualified Negroes who are the victims of discrimination. The statute requires individual actions in each case of suspected discrimination. The United States must move in each voting district of each State in which complaining Negroes are being treated unfairly. Each suit requires intensive investigation and the careful construction of a convincing record-no easy task. Each suit requires local Negro witnesses who are willing to overcome a reluctance to cooperate because of fear of possible economic or physical retaliation by the white commumity. Each suit is susceptible to all the delaying tactics possible in civil litigation, and each decree rendered by a local district court is subject to a lengthy appellate review.

Since the passage of the Civil Rights Act of 1957 only a limited number of suits have been brought, and these have lingered long in the litigation process. ${ }^{77}$ This is undoubtedly due to some or all of the factors mentioned

and $0.07 \%$ of the white voters, that members of the council and election officials limited their examination almost exclusively to registration records of Negro voters, and that errors and deficiencies leading to the disenfranchisement of the Negro voters existed in the registration records of numerous whites who were not challenged. 180 F. Supp. at 11, 13.

77 The Report states that as of September 9, 1959, the United States had instituted only three actions under $\$ 1971$ : in Terrell County, Georgia; Macon County, Alabama; and Washington Parish, Louisiana. Report 131-32.

The Georgia action was dismissed on the grounds that $\$ 1071$ is unconstitutional. United States v. Raines, 172 F. Supp. 552 (M.D. Ga. 1959), rev'd,'80 Sup. Ct. 519 (1960); see text at notes 69-76 supra.

The Alabama action collapsed because of the resignation before suit of the board of registrars named as defendant. The United States attempted to maintain the action against the State of Alabama but was thwarted when the district court and court of appeals held that $\$ 1971$ did not contemplate an action against a State. United States v. Alabama, 171 F. Supp. 720 (M.D.Ala.), aff'd, 267 F.2d 808 (5th Cir. 1959). Certiorari was granted in the case, and argument should be heard during the present term of Court. 80 Sup. Ct. 196 (1959) (No.398). The issue presented by this case has lost most of its significance in view of the provision in the recently adopted act permitting the United States to institute or continue election proceedings against a State.

The Louisiana complaint survived a motion to dismiss, United States v. McElveen, 177 F. 
above. Moreover, success in each of these suits would only qualify a limited number of Negroes. ${ }^{78}$ Perhaps it can be predicted that the issuance of final decrees in these cases will have a carryover effect on the rights of other Negroes in other districts. But even if this is true, in view of the difficulties inherent in a remedy which depends on individual law suits section 1971 can only have a minimal impact on the problem of getting significant numbers of qualified Negroes registered to vote.

\section{The New Remedy}

Because of the inadequacies of existing remedies the Commission and the administration put forth proposals designed to solve the problems of voting discrimination. The Commission's proposals called for executive action. The administration's recommendation called for judicial enforcement. Other proposals combined both approaches. Congress adopted the administration plan. ${ }^{79}$

The new remedy first requires a suit by the Attorney General under section 1971(c) in behalf of one or more individuals who allegedly have been deprived of voting rights because of race or color. If the suit is successful the Attorney General can ask the court to determine whether the individuals concerned were deprived of their voting rights pursuant to a pattern or practice. Upon a determination that they were, all persons of the same race or color in the area administered by the defendant election officials are entitled to apply to the court for orders declaring that they too are qualified to vote at any election. Such orders are to be issued after each applicant has proved that he is qualified to vote under state law and that since the court's finding of the prohibited pattern or practice he has been found unqualified by a state election official or has been otherwise denied the opportunity to register or qualify. The district courts are directed to hear these applications within 10 days of their filing. Orders issued are effective for any election held within the usual registration period provided

Supp. 355 (E.D. La. 1959), and was brought to a successful conclusion in the district court which ordered the reinstatement of Negro voters to registration lists from which they had been purged on a discriminatory basis. United States v. McElveen, 180 F. Supp. 10 (E.D. La. 1960). The decree was affirmed, sub nom. United States v. Thomas, 80 Sup. Ct. 612 (1960).

A fourth action involving Fayette County, Tennessee, was successfully concluded with the entry of a consent judgment requiring the County Democratic Committee to register qualified Negroes for primary elections. N.Y. Times, Apr. 26, 1960, p. 1, col.3.

78 At most, the only Negroes who would be qualified by such a decree would be those within the voting subdivision administered by the defendant election officials.

79 Civil Rights Act of 1960, 74 Stat. 86 (P.L. 86-449, approved May 6, 1960).

The administration submitted an original and revised version of its proposal. The original plan is embodied in a number of bills introduced in both Houses of Congress. H.R. 10018, 86th Cong., 2d Sess. (Jan. 28, 1960, Congressman Goodsell); H.R. 10034, 86th Cong., 2d Sess. (Jan. 28, 1960, Congressman Lindsay); H.R. 10035, 86th Cong., 2d Sess. (Jan. 28, 1960, Congressman McCulloch); S.3001, 86th Cong., 2d Sess. (Feb. 8, 1960, Senator Dirksen). 
by state law. The Attorney General transmits copies of the orders to appropriate state officials who are subject to contempt of court for failing to permit those named in the orders to vote. A stay of such an order is forbidden where its effect would be to preclude the applicant from voting at any election.

The plan envisages the use of voting referees to receive the applications, take evidence at specified times, and make appropriate reports to the courts. The proceedings before the referees are designed to be simple. The applicant is to be heard ex parte-his statement under oath being prima facie evidence of age, residence, and prior efforts to register. The referee makes a report to the district court stating whether or not the applicant is qualified to vote and whether or not he has been denied the opportunity to vote by state officials. If the report indicates that the applicant is qualified and has been denied registration by state officials, the district court will order the Attorney General to transmit a show-cause order returnable within 10 days to appropriate state officials who may file exceptions and memoranda of law. If the memoranda or exceptions, supported by required public records or personal affidavits, indicate a disputed question of material fact, either the district court or the referee is required to hold a hearing which presumably must be public. However, the applicant's literacy is not subject to further examination. If the court determines that the applicant is qualified, it issues to him a certificate stating his eligibility which must be honored by state election officials who are otherwise subject to contempt of court. The district courts have authority to issue orders provisionally entitling applicants to vote pending determination of their applications. ${ }^{80}$

Insofar as the new remedy relates to federal elections, it appears clearly constitutional as an exercise of congressional power to regnlate federal elections. ${ }^{81}$ Insofar as it relates to state and local elections it appears to be "appropriate legislation" to implement the fifteenth amendment, since eligible candidates are qualified to vote only after the district court has concluded that they have by state action been denied the right to register or to vote because of their race or color. ${ }^{82}$

80 In the case of applications filed 20 or more days prior to an election, which are undetermined by the time of such election, the act directs the court to issue an order entitling the applicant to vote provisionally. If the application was filed less than 20 days prior to the election, the court may in its discretion issue such an order. In neither case, however, may such an order be issued unless the "applicant shall be qualified to vote under State law." This seemingly contradictory provision which appears to require the court to make its ultimate determination in order to authorize a provisional vote pending that determination was the product of an unexplained last-minute amendment in the Senate. It would seein, however, that at most the provision requires the court to affirm the referee's conclusion of the applicant's eligihility, but not the finding of discriminatory treatment by state election officials, before a provisional authorization is issued. The act also empowers the court to issue appropriate orders for the impounding of provisional ballots.

81 See text at notes $31-44$ supra.

82 Ibid. 
Opponents of the new act undoubtedly will argue that the duties devolving on the federal courts are not properly within the "judicial function." But this argument seems weak. A federal court, properly authorized by Congress, is empowered to issue orders directing state election officials to register qualified Negroes who, in the course of a judicial proceeding, have been found to have been denied voting rights because of race discrimination. ${ }^{83}$ The act merely provides for referees (having the powers of masters) to aid the court in discharging this function. The referees may review the facts and determine whether or not the applicants are qualified and whether or not they have been the victims of racial discrimination. The referees advise the district court, and the court makes the final determination of discrimination. The court then directs the appropriate state election officials to permit the qualified applicants to vote and enforces its orders through contempt proceedings. Each application to the referees and court presents a legitimate controversy with true adversaries (the applicant and the registrar), and the court's decree is a final adjudication of the rights of the applicant.

\section{III}

THE COMPETING PROPOSALS

The competing proposals that were rejected by Congress called for executive action or for a combination of executive and judicial proceedings. ${ }^{84}$

\section{A. The Commission's Plan}

The Commission's plan, ${ }^{85}$ as embodied in a number of Senate bills, provided for a five-step process. First, the process was set in operation if in the course of 1 year at least nine persons in a state election district

83 Byrd v. Brice, 201 F.2d 664 (5th Cir. 1953) ; Rice v. Elmore, 165 F.2d 387 (4th Cir. 1947), cert. denied, 333 U.S. 875 (1948); United States v. Raines, 172 F. Supp. 552, 556 (M.D. Ga. 1959), rev'd on other grounds, 80 Sup. Ct. 519 (1960); Dean v. Thomas, 93 F. Supp. 129 (E.D.La. 1950) ; Davis v. Schnell, 81 F. Supp. 872 (S.D. Ala.), aff'd, 336 U.S. 933 (1949); Comment, 43 CoRNeLr. L.Q. 661 (1958). On this same general topic as applied to analogous areas, sec Comment, 22 U. CrI. L. REv. 657 (1955).

84 It rccently came to the author's attention that on February 14, 1960, a conference on civil rights was held at the University of Notre Dame Law School. The procecdings are printed in 106 Covg. Rec. A1706-34 (daily ed. Feb. 29, 1960). The conference produced a number of excellent and detailed analyses of the competing voting proposals.

85. REPORT 141-42. Commissioner Battle disagreed with the proposal. Ibid.

${ }^{86}$ The following bills were introduced embodying the Commission's proposal. S.2684, 86th Cong., 1st Sess (Sept. 11, 1959, Senator Humphrey); S. 2719, 86th Cong., 1st Sess. (Sept. 14, 1959, Senator Morse); S. 278.3, 86th Cong., 2d Sess. (Jan. 11, 1960, Senator Javits) ; S. 2814, 86th Cong., 2d Sess. (Jan. 14, 1960, Senators Humphrey, Hart, McNamara, Douglas, Clark, McCarthy); H.R. 10140, 86th Cong., 2d Sess. (Feb. 2, 1960, Congressman Lindsay). 
petitioned the President by affidavit setting forth facts showing they had been denied the right to register to vote because of their race, religion, color, or national origin. Second, the President was directed to refer the petitions to the Civil Rights Commission to investigate the validity of the allegations and to certify to the President all well-founded affidavits. Third, the President, upon such certification, was required to designate as a temporary registrar an existing federal officer or employee in the area from which the complaints were received. Fourth, the registrar was directed to administer the state qualification test to all individuals within the district who alleged they were being denied the right to register because of their race, religion, color or national origin, and to issue to those found qualified certificates entitling them to vote for federal officials. Fifth, the registrar was required to certify the qualified individuals to state election officials who could be punished in a criminal action for failing to permit those qualified to vote. The registrar was to continue in office until the President was satisfied that persons in the election district no longer were subject to discrimination.

The plan appeared free from constitutional doubt. It found support in the congressional powers to regulate federal elections and to pass "appropriate" legislation to enforce the fourteenth and fifteenth amendments. ${ }^{87}$ The proposal related solely to federal elections. The Constitution provides Congress with plenary power to regulate such elections (other than prescribing the qualifications of voters) and thus the source of congressional authority was clear. ${ }^{88}$ In addition, the plan was designed to eradicate all state-imposed discrimination in voting that is based on race, religion, color or national origin. These ends are within the coverage of the fourteenth and fifteenth amendments. ${ }^{89}$ The procedure chosen by the Commissionthe appointment of temporary federal registrars-seemed legitimately related to these purposes; the plan appeared clearly to come within the classification of "appropriate legislation."

It was argued by certain Congressmen that the Commission's plan was unconstitutional because under it state election officials could be deprived of "property"-their jobs-without "due process of law." But the short answer is that state election officials would continue to register all voters who did not claim discriminatory treatment; their jobs, even if classified as "property" for due-process purposes, would hardly be in jeopardy. In addition, the plan envisaged investigations at which the election officials presumably would have had ample opportunity to defend against the charges of discrimination.

87 See text at notes $31-44$ supra.

88 Ibid.

89 Ibid. 


\section{B. The Hennings' Proposal}

The Hennings' plan, ${ }^{90}$ a third proposal, combined the approaches of both the Commission and administration. The Hennings' proposal followed the Commission's plan, in providing for the appointment of registrars by the President. It required, however, the submission of petitions from 50 or more individuals from the same county; each petitioner was required to allege that he was qualified to vote in federal elections and that he believed that citizens in his county were being denied the right to vote on the basis of their race or color. The President, if he wished, could utilize the Civil Rights Commission, the Departnent of Justice, or any appropriate federal agency to investigate the allegations. Unlike the Commission's plan, the Hennings' plan, called for the designation by the President of the class of persons who were found to be the object of discriminatory treatment in a particular county, and permitted members of the class in that county to be registered to vote in federal elections without proof that as individuals they had been treated in a discriminatory fashion. The plan further provided that the registrar's decisions could be challenged in federal district court, but that the registrar's determinations stood pending such litigation and appeal. The Hennings' bill also included the administration's voting referee plan without substantial modification.

The proposal appeared to satisfy constitutional prerequisites for the reasons stated in connection with the Commission's plan and the new law finally adopted. There might have been some doubt whether the receipt of 50 petitions, indicating the affiants' behefs that some citizens (not necessarily the affiants) were being denied voting rights on the basis of race or color, should have been a sufficient showing to justify federal intervention. But no constitutional doubts were created because the registrar portion of the plan related solely to federal elections with respect to which the Congress' power is plenary.

IV

\section{CRITIQUE}

In view of Congress' action, it is most pertinent to determine whether the administration's plan-the act as passed-provides a realistic remedy for disenfranchised Negroes. It also seems of value to analyze the rejected proposals briefly, as the possibility remains that a future legislature will enact further measures to aid qualified Negroes to register and vote.

The administration repeatedly has urged that its measure is workable and effective. The claim does not seem reahistic for the same reasons that have limited the efficacy of the 1957 act.

${ }^{20}$ S. 3045, 86th Cong., 2d Sess. tit. 5 (Feb. 16, 1960). It was the product of Senator Hennings' Subcommittee on Constitutional Rights. 
First, many Negroes, especially those in the deep South, will be deterred from invoking the procedures of the new act by the fear of economic or physical retaliation. The remedy created by the act requires individual Negroes to claim discriminatory treatment at the hands of white election officials and to request that the United States bring a suit under section 1971(c) ${ }^{91}$ Other Negroes wishing to gain the benefits that might flow to the initiators must identify themselves to state election officials, by trying to register, and then to a referee and a district court. Their names cannot be kept confidential because the act envisages at some stage an open hearing at which contrary evidence can be received. Thus, Negroes, to invoke the remedy of the act, must bring publicized charges against locally powerful officials. This will make these Negroes identified targets for coercion and intimidation. The threat of such conduct will undoubtedly influence significant numbers to forego the remedy.

The Commission's plan was no more realistic on this score. Under it Negroes who initially petitioned the President had to make charges of discrimination which were subject to open investigation by the Civil Rights Commission. Other Negroes wishing to register with the appointed federal officials had to make similar charges.

The Hennings' plan was an improvement, for under it all members of a designated class could register with federal officials without bringing charges and without specially singling themselves out as leaders of a movement against the established order. Of course the Hennings' plan still required fifty initial petitions from Negroes willing to become involved in publicized investigations. Also, to the extent that the Hennings' plan adopted the administration's referee proposal it was subject to the criticisms leveled at the latter.

A second weakness of the new law is that delays in registering large numbers of Negroes are inherent under it. The act envisages investigations in each election district after initial actions by a few Negroes. Next follows full-scale litigation. Finally, a district court, after recommendations by a voting referee, must make a person-by-person determination of qualification after each prospective Negro voter has unsuccessfully attempted to register with state officials and has had that attempt witnessed by persons willing to testify. While the act permits concurrent suits in many districts, each action entails a detailed investigation, the meticulous construction of a persuasive record, and a presumably long law suit.

The Commission's plan would also have subjected Negroes to considerable delay. It too called for investigations by the Civil Rights Commission -or more realistically its staff-in each election district after initial action 
by a few Negroes. Also, an unsuccessful attempt at state registration was evidently a necessary condition to federal registration.

Again the Hennings' proposal, insofar as it provided for the appointment of federal registrars, was an improvement, for under that plan, registrars would be appointed for counties rather than election districts and their appointment would not have had to be preceded by investigations if the President was otherwise satisfied that discrimination was occurring. It is perhaps doubtful, however, to expect that the President would act without an investigation.

Third, the act requires the federal judiciary to enforce Negro voting rights. This seems unwise. Federal judges in the South are already under extreme pressure from local forces in school desegregation matters. To ask these same judges to incur the wrath of the community in voting cases, when other, more practical, alternatives exist, is to ask them to shoulder too much of the burden.

The Commission's proposal and that portion of the Hennings' plan calling for the appointment of registrars properly put the responsibility for voting reforms in the executive department. But unfortunately they required action at too high a level. Both plans called for Presidential action involving small political subdivisions. It seems unrealistic to expect prompt consideration at that level. Moreover, the plans would have pitched the White House into local political battles where it is conceivable that pressures froin party sources might delay or obstruct prompt action.

Fourth, the act requires interested Negroes who were not involved in the injunction suits brought by the Attorney General to enter into the arena of the law court in order to vote. It seems unrealistic to expect that a group of persons admittedly disadvantaged in economic and education matters would embrace in significant numbers this complex procedure. Of course organizational activity by the NAACP could alleviate this difficulty.

\section{V}

\section{A BETTER SOLUTTON-THE HART PROPOSAL}

An effective means to enfranchise significant numbers of qualified Negroes in a relatively short time is suggested by a bill ${ }^{82}$ proposed by Senator Hart which was never the subject of serious congressional consideration. His plan contemplated a congressional elections commission which would have unfettered discretion to register, under state qualification standards, applicants to vote for Senators and Representatives in primary, special and general elections. In addition, the Hart bill permitted a com-

82 S. 2535, 86th Cong., 1st Sess. (Aug. 12, 1959) (Senator Hart for himself and Senators Gruening, McCarthy, Proxmire, Engle, McNamara, Williams, Douglas, Randolph, Morse, Clark, Hennings, Chavez, Allott, and Neuberger). 
mission created by the plan to administer the elections for these offices if requested by the State in which the congressional district was located or if the commission determined that properly registered and qualified persons were likely to be denied access to the polls. The commission could also in its discretion decide to utilize state agencies to conduct the registration or election activities.

The Hart approach seems best designed to qualify rapidly large numbers of eligible Negro voting applicants. It undoubtedly should be broadened to cover the full gambit of federal offices-including the electors for President and Vice-President. Clearly Congress' plenary power to regulate federal elections extends this far..$^{93}$ The strengths of this approach include: (1) a simple means for permitting significant numbers of Negroes to register and vote without having to single themselves out for coercion, intimidation, and retaliation; (2) a method to avoid the delay inherent in litigation and investigation to establish the existence of discrimination; (3) a procedure that does not involve the federal judiciary; and (4) a plan that avoids the necessity of high level decisions in each voting controversy.

There are undoubtedly some weaknesses even in this approach. First, the plan did not provide for direct federal participation in the qualification of voters for state elections. The Attorney General pointed out forcefully in his testimony before the Senate Committee on Rules and Administration that this was a drawback of the Commission's registrar proposal which the administration's bill cured. ${ }^{\text {of }}$ But it seems obvious that any politically palatable scheme for federal supervision of all elections must necessarily be based on congressional power under the fifteenth amendment and will involve review of the actions of state registration officials, thereby occasioning delay and, more importantly, the identification of the protesting Negroes. ${ }^{95}$ To this writer these are more serious drawbacks than is the partial coverage of the Hart plan. Moreover, a plan calling for federally supervised registration for federal elections would undoubtedly effect a change in state registration and voting procedures; state officials would probably be reluctant to disqualify Negroes who had been qualified under the same standards of eligibility by federal officials since such Negroes would have readily available evidence to show violations of the civil and criminal provisions of the Civil Rights Acts. ${ }^{96}$ Here the threat of criminal punishment or monetary loss would be a factor with which state registrars would have to contend.

93 See text at notes 31-44 supra.

94 Testimony of Attorney General William P. Rogers Before the Senate Rules and Administration Committee on Proposed Civil Rights Legislation, U.S. Dep't of Justice Press Release, Feb. 5, 1960.

85 See text at notes $45-65$ supra.

96 See text at notes 54-55 supra. 
The second objection to the Hart approach is the expense which it would entail since it could result in the creation of a separate machinery for state and federal elections. This objection is well taken but is not as serious as might immediately appear. First, a federal elections commission should be given the discretion to use state registration and election machinery whenever, in its view, there is no substantial fear of discrimination. In effect this was provided by the Hart bill. This would make it unnecessary to set up separate federal procedures in a majority of the States. Second, such a commission should be given the discretion to accept state registration for federal purposes. This would make it unnecessary to examine most of the applicants and would reduce federal registration in such cases to bookkeeping entries. In fact, this simple device would automatically qualify most of the potential voters. A local federal official, perhaps a postmaster or United States Attorney, could then test those applicants that were found disqualified by state election officials or that sought only federal registration. It will undoubtedly be argued that such a procedure would lead to segregated registration. Perhaps this is true. But segregated registration seems better than no registration at all. Moreover, if segregated registration is deemed a sufficient evil, the elections commission could be directed to register all applicants, including those previously registered by state officials.

\section{CONCLUSION}

All of the proposals surveyed made commendable efforts to solve the vexing problem presented by the discriminatory application by some state election officials of valid qualification standards for voting. To this writer, the simple approach of Senator Hart makes the most sense. Unfortunately the least effective proposal was that adopted by Congress-the administration's plan. It necessitates complex judicial action leading to delay and to the identification and concommitant coercion of individuals trying to use the procedure. Perhaps a future Congress will go further if these pessimistic expectations are realized. This hope is nurtured by the fact that few thought Congress only 3 years after adopting the provisions contained in the Civil Rights Act of 1957 would take additional action designed to assure the right of a disenfranchised minority to participate in the Nation's political affairs. 


\section{APPENDIX}

Percentages of Nonwhite Voting Registration in the South

Florida

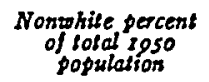

Nonwhise percen population

Gadsden . . . . . . 56.1

Georgia

Baker . . . . . . . 61

Burke . . . . . . . 71.3

Calhoun . . . . . . 67.5

Lee . . . . . . . 71.3

Macon . . . . . . . 66.1

Marion - . . . . . 59.2

Stewart . . . . . . . 72.5

Terrell . . . . . . . 67.2

Webster • • . . . . 63.9

\section{Louisiana}

Claiborne . . . . . 51.7

East Carroll . • • . . 61.1

Madison . . . . . 66.2

Red River . • • • • 50.0

Tensas . . . . . . . 64.8

West Feliciana . • • . $\quad$. 71.2

South Carolina

Calhoun . . . . . . 70.8

McCormick . . . . . 62.6

Alabama

Bullock . . . . . . . 73.6

Lowndes . . . . . 82.2

Marengo . . . . . . 69.4

Wilcox • . • . . • . 79.1

Mississippi

Amite . . . . . . . 54.2

Carroll . . . . . . . 57.0

Clay . . . . . . . 56.9

Copiah . . . . . . . 53.4

De Soto . . . . . . 67.2

Grenada . . . . . . 52.2

Holmes - . . . . . 73.5

Humphreys . - . - . 69.7

Issaquena - . . - . . 67.4

Jefferson . • . • . • 74.5

Marshall • • • • • . 70.6

Noxubee . . . . . . 74.4

Sbarkey . . . . . . 713

Tallahatchie . . . . 63.7

Tate . . . . . . 57.6
Percentage of 3950 nomohlle population over as ressered is 3958

0.6 0

4.1

1.1

3.7

2.8

3.1

0.95

0

0.2

0

0

0.5

0

0

1.7

0

0.9

0

1.2

0

0.07

0

0.24

0.2

0.01

0.78

0.39

0.48

0

0

0.18

0

0.02

0

0 
On the other hand, in a few Southern counties with a majority of Negro inhabitants a significant percentage of Negroes are registered. E.g.:

\section{Georgia}

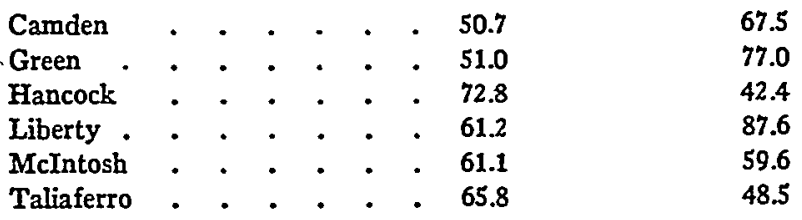

Louisiana

St. Helene - • • • • - $53.1 \quad 52.3$

St. James . . . . . $50.3 \quad 58.4$

Virginia

Charles City . . . . $\quad$ - $81.0 \quad 36.5$

New Kent • • • • • $54.0 \quad 32.5$ 